\title{
RITUAL MASYARAKAT BANJAR DAN DAYAK DALAM NOVEL JENDELA SERIBU SUNGAI KARYA MIRANDA DAN AVESINA: KAJIAN ANTROPOLOGI Ritual of Banjar and Dayak People in the Novel Jendela Seribu Sungai by Miranda and Avesina: An Antropological Study
}

\author{
Firlana Izaty \\ Purwati Anggraini \\ Pendidikan Bahasa dan Sastra Indonesia \\ Universitas Muhammadiyah Malang \\ Jalan Tlogomas No. 246 Tlogomas, Lowokwaru, Malang, Jawa Timur, Indonesia \\ firlana.rekafirza@gmail.com
}

Diterima 09 Oktober 2019

Direvisi 16 Februari 2021

Disetujui 18 Februari 2021

https:// doi.org/10.26499/und.v16i2.2737

\begin{abstract}
Abstrak: Tujuan dalam penelitian ini yaitu memperkenalkan kegiatan ritual sebagai suatu bagian dari kebudayaan yang ada dalam masyarakat Banjar dan Dayak, baik dalam segi arti dan tujuan pelaksanaan ritual tersebut. Alasan memilih novel ini karena novel Jendela Seribu Sungai tidak hanya menceritakan kehidupan si tokoh utama,, namun juga menyisipkan arti dari nilainilai budaya dari daerah dan kehidupan yang berbeda-beda. Pengarang mampu menggabungkan dua kehidupan yang berbeda yaitu kehidupan masyarakat Banjar yang modern dengan kehidupan masyarakat Dayak yang tertinggal. Penelitian ini menggunakan metode deskriptif analitik kualitatif. Metode kualitatif dengan memberikan perhatian terhadap data alamiah, data dalam hubungannya dengan konteks keberadaannya. Teknik pengumpulan data yang digunakan dalam penelitian ini adalah teknik baca catat dan riset kepustakaan. Antropologi sastra muncul sebagai suatu usaha untuk mencoba memberikan identitas terhadap karya sastra dengan menganggapnya sebagai suatu hal yang mengandung aspek tertentu yang berhubungan dengan cirri kebudayaan. Pada novel Jendela Seribu Sungai ada beberapa ritual yang sering dilakukan bahkan menjadi warisan turun temurun, diantaranya: Tian Mandaring, Mandiwata Bapanaik dan Aruh Ganal, Proses Tatamba, dan Bagandang Nyiru/Upacara Wadian.
\end{abstract}

Kata-kata Kunci: Ritual, Sikap Hidup, Antropologi Sastra

Abstratc: The purpose of this research is to introduce ritual activities as part of the culture that exists in the Banjar and Dayak communities, both in terms of the meaning and purpose of the ritual implementation. The reason for choosing this novel is because the Jendela Seribu Sungai not only tells the life of the main character from different regions and lives. The author is able to combine two different lives, namely the life of the modern Banjar people with the lives of the lagging Dayak people. This research uses descriptive analytic qualitative method. Qualitative methods by giving attention to natural data, data in relation to the context of its existence. Data collection techniques used in this study were literacy and library research techniques. Anthropology of literature emerged as an effort to try to give identity to literary works by considering it as something that contains certain aspects related to cultural characteristics. In the Jendela Seribu Sungai novels there are some rituals that are often performed even as a hereditary legacy, including: Tian Mandaring, Mandiwata Bapanaik and Aruh Ganal, Tatamba Process, and Bagandang Nyiru Wadian Ceremony.

Keywords: Cultural Identity, Life Attitude, Literary Anthropology 


\section{PENDAHULUAN}

Indonesia merupakan Negara yang memiliki banyak pulau, ada pulau Jawa, Sumatera, Kalimantan dan masih banyak lagi. Indonesia juga merupakan Negara dengan berbagai macam suku dan kebudayaan. Menurut (Macionis Faruk, 2012) dalam (Wanti, 2014) kebudayaan sebagai nilai, keyakinan, perilaku dan materi (material objects) yang mengatur kehidupan masyarakat (hlm. 2). Budaya juga dikatakan sebagai suatu pikiran, adat istiadat yang sudah menjadi kebiasaan yang kemudian sukar atau sulit untuk diubah. Setiap daerah yang ada di Indonesia tentunya memiliki kebudayaan yang beragam dan setiap kebudayaan memiliki ciri khas yang berbeda pula. Setiap daerah dengan keanekaragaman budayanya tentunya memiliki kearifan lokal yang berbeda-beda. Berbagai macam kearifan lokal ini yang kemudian menjadi salah satu identitas budaya, dengan kearifan lokal pula suatu daerah mampu menjadikan daerah tersebut memiliki jati diri yang tentunya juga berpengaruh terhadap watak, karakter, serta proses kehidupan pada masarakat dalam daerah itu.

Secara umum kearifan lokal dapat dikaitkan dengan pola kehidupan masyarakat ataupun keadaan komunitas setempat dalam menjalin hubungan antara individu dengan dirinya sendiri, individu dengan individu lain, individu dengan kelompok sosial, individu dengan alam, dan individu dengan sang pencipta (Ratna, 2011, hlm. 114). Semua hubungan itu dilaksanakan dengan tujuan untuk menjamin keberlangsungan hidup komunitas secara khas. Dalam hal ini, kearifan lokal umumnya dikaitkan dengan kehidupan komunitas tradisional. Jika kearifan lokal secara umum sering dikaitkan dengan komunitas tradidional, tidak menutup kemungkinan kearifan lokal juga dapat muncul ataupun terjadi pada masyarakat modern (Herusatoto, 2005 dalam Astutik, 2012, hlm. 12)

Kearifan lokal sendiri memiliki beberapa macam, diantaranya seperti yang akan dibahas pada penelitian ini yaitu ritual. Ritual sendiri memiliki arti sebagai serangkaian acara ataupun tindakan yang di dalamnya melibatkan suatu kepercayaan atau magic, yang dari kedua hal itu kemudian dijadikan atau dimantapkan sebagai tradisi (Sulastri, 2017, hlm. 38). Ritual juga dapat dikatakan sebagai suatu kegiatan atau perilaku yang sifatnya cenderung formal dan dilakukan dengan cara yang berbeda dan dalam waktu tertentu saja. Ritual bukan hanya sebagai rutinitas yang ada pada suatu daerah, akan tetapi juga sebagai tindakan yang didasarkan pada suatu keyakinan religius terhadap suatu kekuasaan atau kekuatan mistis yang dipercaya oleh masyarakat dalam daerah tertentu (Wanti, 2014, hlm.16).

Dalam ritual sendiri dibedakan menjadi beberapa bagian yaitu ada ritual adat dan ritual keagamaan. Ritual adat diartikan sebagai suatu kebiasaan yang kegiatan tersebut sudah melekat pada masyarakat secara turun-temurun yang juga mencerminkan identitas mereka. Sedangkan ritual keagamaan dikatakan sebagai suatu tindakan masyarakat dengan tujuan untuk mendekatkan diri kepada tuhannya dengan tujuan agar dalam kehidupan di dunia dan kehidupan yang akan 
datang terdapat suatu kebahagiaan, hal ini diakini dengan sepenuh hati dan juga didasarkan atas kepercayaan terhadap agama yang dianut oleh masyarakat itu sendiri.

Seperti halnya dalam novel Jendela Seribu Sungai karya (Miranda \& Avesina, 2018) yang juga membahas tentang berbagai macam ritual yang masih ada dan tetap dikembangkan oleh masyarakat Banjar dan Dayak. Penulis dalam novel ini berhasil membawa pembaca untuk menikmati setiap serangkaian proses ritual yang diceritakannya. Novel ini bercerita tentang keadaan hidup masyarakat Banjar dan Dayak yang mulai berubah di era modern. Masyarakat Dayak yang cenderung menolak moderniasi terutama dalam hal pendidikan dan kesehatan. Alasan mereka menolak karena mereka khawatir melawan kearifan lokal yang diwariskan leluhur mereka secara turun-temurun. Pada masyarakat Banjar pula yang dulunya menjadikan sungai sebagai kiblat hudupnya kemudian berubah dengan adanya jalan raya. Masyarakat Banjar dalam novel ini juga diceritakan terjadinya perang saudara yang kemudian pecah menjadi dua bagian yaitu masyarakat Banjar Antasan Timur dan Antasan Barat. Pada masyarakat Antasan Timur digambarkan sebagai kawasan dengan kekumuhan, kemiskinan dan lain sebagainya, sedangkan pada Antasan Barat merupakan kawasan dengan kemewahan, kepandaian, kekayaan dan juga kesombongan.

Penelitian relevan dilakukan oleh Sulastri (2017) pada jurnal Pendidikan Bahasa Vo. 6 No. 1 tahun 2017 dengan judul Unsur-unsur Budaya Dayak Iban dalam Novel Keling Kumang karya Ray
Masri Sareb Putra. Hasil penelitian dalam penelitian ini mengungkapkan tentang unsur-unsur budaya Dayak Iban di Kalimantan Barat dengan menggunakan kajian antropologi sastra. Penelitian ini menuliskan unsur-unsur budaya dengan memperhatikan beberapa dimensi, yaitu: bahasa, religi, mitos, adat istiadat, mata pencaharian, kesenian, dan sistem pengetahuan.

Perbedaan dengan penelitian yang saya lakukan yaitu yang pertama dalam penggunaan objek penelitian, jika pada penelitian Salustri menggunakan objek Dayak Iban dalam novel Keling Kumang, sedangkan penelitian ini menggunakan objek masyarakat Banjar dan Dayak dalam novel Jendela Seribu Sungai. Perbedaan selanjutnya dapat dilihat dari pembahasan yang akan dilakukan. Jika dalam penelitian terdahulu membahas tentang unsur-unsur dalam masyarakat Dayak dalam novel Keling Kumang secara keseluruhan, sedangkan penelitian yang saya lakukan membahas tentang persamaan pelaksanaan kegiatan ritual oleh masyarakat Banjar dan Dayak dalam novel Jendela Seribu Sungai.

Dalam penelitian lainnya yang dilakukan oleh Rafiq (2013) pada jurnal Albanjari Vol. 12 No. 1 tahun 2013 dengan judul Relasi Dayak-Banjar dalam Tutur Masyarakat Dayak Meratus. Penelitian ini juga mengkaji masyarakat Dayak dan Banjar sebagai objek dalam penelitiannya. Hasil yang didapat dalam penelitian ini yaitu adanya perbedaan pendapat antara kedua suku ini, disebutkan oleh peneliti bahwa terdapat simbol-simbol yang membedakan tipografi relasi antara Dayak dan Banjar. Dilanjutkan dengan penjelasan bahwa setidaknya ada 
empat tipologi relasi yaitu: relasi geneologis, analogis, kooperatif, dan histori.

Selain itu, indrawati (Indrawati, 2020) juga meneliti novel Jendela Seribu Sungai karya Miranda dan Avesina dengan menggunakan pendekatan etnolinguistik. Hasilnya tradisi dan adat kebiasaan masyarakat Banjar dan Dayak masih dilaksanakan seperti, ungkapan dan peribahasa Banjar dan Dayak yang menjadi pondasi dan pedoman masyarakatnya; ritual dan kepercayaan berupa mantra dan doa yang diyakini dan dibaca pada setiap prosesi upacara, permainanan rakyat yang masih letari dimainkan.

Penelitian terdahulu ini jelas memiliki perbedaan dengan penelitian yang kami lakukan. Persamaan hanya terletak pada onjek yang dikaji saja, yaitu kebiasaan dan atau kepercayaan yang dianut oleh masyarakat Banjar dan Dayak.

Seperti judul yang tertera pada penelitian ini, yaitu "Ritual Masyarakat Banjar dan Dayak dalam Novel Jendela Seribu Sungai Karya Miranda dan Avesina: Kajian Antropologi". Alasan mengangkat tema ritual masyarakat yang ada pada masyarakat Banjar dan Dayak karena kedua daerah ini hidup secara berdampingan yang hanya dipisahkan dengan sungai dan gunung. Ritual yang mereka lakukan juga hampir sama, hanya saja perbedaannya terletak dari cara mereka membawakan ritual tersebut dengan bacaan-bacaan, yang oleh masyarakat Dayak dikenal dengan mantra sedangkan untuk masyarakat Banjar lebih dikenal dengan sebutan doa-doa.

Mengapa memilih novel Jendela Seribu Sungai karya Miranda dan Avesina, karena dalam novel ini tidak hanya menceritakan kehidupan si tokoh utama dari daerah dan kehidupan yang berbeda-beda. Pengarang mampu menggabungkan dua kehidupan yang berbeda yaitu kehidupan masyarakat Banjar yang modern dengan kehidupan masyarakat Dayak yang tertinggal. Dalam menuliskan cerita antara perbedaan yang kuat dari dua daerah ini, pengarang seakan menarik pembacanya seperti ikut melakukan perjalanan panjang seperti yang diceritakan dalam novel. Novel ini tidak hanya menawarkan cerita yang menarik, namun juga mampu memperkenalkan tradisi dan kekayaan yang ada antara dua daerah yang diceritakan dalam novel. Antropologi dipilih dengan alasan bahwa antropologi merupakan suatu ilmu yang di dalamnya membahas suatu kebudayaan salah satunya. Antropologi juga membahas tentang manusia, khususnya tentang asal-usul, bentuk fisik, adat istiadat, serta kepercayaan yang dipegang hal ini tentu sangat sesuai dengan pemilihan tema yang nantinya akan dibahas.

Dari penjelasan di atas, masalah yang akan diangkat dalam penelitian ini yaitu pembahasan tentang jenis ritual antara masyarakat Dayak dan Banjar yang memiliki kesamaan seperti yang diceritakan dalam novel Jendela Seribu Sungai karya Miranda dan Avesina. Tujuan dalam penelitian ini yaitu memperkenalkan kegiatan ritual sebagai suatu bagian dari kebudayaan yang ada dalam masyarakat Banjar dan Dayak, baik dalam segi arti dan tujuan pelaksanaan ritual tersebut. Di samping tujuan yang dijelaskan sebelumnya, penelitian ini juga menjelaskan beberapa ritual yang hampir memiliki 
kesamaan arti dari dua suku ini, yaitu Banjar dan Dayak.

\section{LANDASAN TEORI}

Ritual yang merupakan tata cara dalam kegiatan upacara atau suatu perbuatan yang dianggap keramat yang dilakukan oleh sekelompok umat beragama dalam suatu daerah tertentu. Ritual ditandai dengan adanya berbagai macam unsur serta komponen yang tidak dapat dilepaskan dengan berlangsungnya kegiatan ritual dengan baik (Amiruddin, 2017, hlm. 4). Komponen yang dimaksud diantaranya waktu, tempat-tempat yang akan melakukan ritual, alat-alat yang akan digunakan, serta orang-orang yang nantinya akan menjalankan ritual atau upacara. Pada dasarnya ritual dikatakan sebagai rangkaian kata, tindakan oleh pemeluk agama dalam daerah tertentu dengan menggunakan benda-benda, peralatan serta perlengkapan tertentu, dilakukan di tempat tertentu dengan memakai pakaian tertentu pula. Misalnya saja dalam upacara kematian, banyak perlengkapan serta benda-benda yang harus dipersiapkan yang nantinya akan dipakai dalam uapacara. Ritual atau ritus misalnya yang dilakukan dengan tujuan untuk mendapatkan berkah atau rezeki yang banyak dari suatu pekerja atau hal lainnya.

Ritual sendiri memiliki berbagai macam tujuan yang nantinya oleh masyarakat yang melakukan ritual itu dapat merasakan kebaikan pada diri mereka. Diantara tujuan dari kegiatan ritual adalah sebagai berikut: ritual dilakukan karena rasa syukur kepada Tuhan, ritual yang dilakukan dengan tujuan mendekatkan diri kepada Tuhan agar mendapat keselamatan dan rahmat, ritual yang dilakukan dengan tujuan mendapat ampunan atas kesalahan yang pernah dilakukan.

Penelitian ini menggunakan teori antropologi. Analisis antropologis digunakan sebagai usaha untuk mencoba memberikan identitas terhadap karya sastra, dengan menganggapnya mengandung aspek tertentu, dalam hubungan ini yang dimaksud adalah ciri-ciri kebudayaan(Ratna, 2013, hlm. 145). Cara yang dimaksud dengan sendirinya berpegang pada definisi antropologi sastra tersebut. Ciri-ciri kebudayaan yang dimaksudkan antara lain: memiliki kecenderungan pada masa lampau, citra primordial, serta citra arketipe. Terdapat juga ciri-ciri lain yang sering digunakan misalnya, mengandung aspek-aspek kearifan lokal yang disertai degan kedudukannya masing-masing, biasanya berbicara tentang suku-suku bangsa dengan subkategorinya masingmasing contohnya seperti trah, klen, dan kasta.

Antropologi sastra muncul sebagai suatu usaha untuk mencoba memberikan identitas terhadap karya sastra dengan menganggapnya sebagai suatu hal yang mengandung aspek tertentu yang berhubungan dengan cirri kebudayaan. Aspek-aspek antropologis dalam karya sastra, meliputi sistem pengetahuan, adat istiadat, sistem kekerabatan, sistem peralatan hidup dan teknologi, mata pencaharian, kesenian, serta sistem kepercayan dan agama menurut (Sudikan, 2007, hlm. 6; dalam Astutik, 2012, hlm. 11). 


\section{METODE PENELITIAN}

Penelitian ini menggunakan metode deskriptif analitik kualitatif. Metode kualitatif dengan memberikan perhatian terhadap data alamiah, data dalam hubungannya dengan konteks keberadaannya (Ratna, 2013, hlm. 165). Metode analisis data yang digunakan dengan mengolah, mengumpulkan data dan analisis data yang akan disajikan. Data-data yang telah dijelaskan sebelumnya kemudian akan ditarik sebuah simpulan dari temuan-temuan yang telah ditemukan dari proses analisis tersebut. Prosedur ini mencirikan bahwa penelitian ini merupakan jenis penelitian kualitatif. Sumber data penelitian ini adalah Novel Jendela Seribu Sungai karya Miranda \& Avesia (2018).

Teknik pengumpulan data yang digunakan dalam penelitian ini adalah teknik baca catat dan riset kepustakaan. Teknik baca catat adalah teknik yang digunakan untuk memperoleh data dengan cara membaca teks atau literatur yang menjadi sumber penelitian dengan memberi tanda pada teks novel Jendela Seribu Sungai karya Miranda dan Avesina. Penelitian kepustakaan dimaksudkan untuk menyatakan suatu cara mengadakan penelitian berdasarkan naskah-naskah yang sudah diterbitkan, baik yang berupa buku, maupun jurnal. Adapun tahapan-tahapan yang dilakukan dalam penelitian ini adalah:

1. Membaca novel Jendela Seribu Sungai karya Miranda \& Avesina dengan berulang-ulang. Hal ini dilakukan agar peneliti memperoleh gambaran secara keseluruhan terhadap novel karya Miranda \& Avesina.
2. Mencatat data-data yang diperlukan dalam penelitian, seperti, kata atau kalimat dan/atau satu kalimat, atau satu paragraf utuh.

3. Melakukan pemilihan ulang terhadap data-data yang akan dianalisis. Hal ini bertujuan untuk mengambil data yang diperlukan dan membuang data yang tidak diperlukan dalam penelitian.

4. Analisis data dilakukan dengan menjelaskan data yang dikutip, manfaat serta tujuan dari data yang diambil.

5. Terakhir yaitu penyajian hasil dalam laporan penelitian.

\section{HASIL DAN PEMBAHASAN}

Dalam pembahasan ini peneliti meneliti kearifan lokal yang difokuskan pada upacara atau ritual pada masyarakat Banjar dan Dayak. Berikut akan dijelaskan beberapa kearifan lokal tentang upacara atau ritual yang ada pada kedua daerah tersebut.

\subsection{Ritual Masyarakat Banjar}

Pada novel Jendela Seribu Sungai ada beberapa ritual yang sering dilakukan bahkan menjadi warisan turun temurun. Meskipun terjadi perpecahan antara masyarakat Banjar Antasan Timur dan Barat pengarang tidak menjelaskan adanya kegiatan ritual yang berbeda, ritual yang ada tetap sama yang berbeda hanya dari tata cara pelaksanaannya. Berikut akan kami tuliskan ritual yang masih ada pada masyarakat Banjar:

\section{Tian Mandaring}

Tian mandaring merupakan kegiatan tujuh bulanan bagi wanita yang hamil untuk pertama kalinya, namun hanya dilakukan oleh orang-orang 
tertentu yaitu keturunan raja. Keturunan raja di sini bukan keduanya (calon ayah dan ibu) adalah keturunan raja, bisa saja calon ayahnya saja yang kemudian calon ibu diwajibkan untuk melakukan ritual mandi ini. Acara ini dilakukan agar bayi yang dalam kandungan ketika proses melahirkan berjalan dengan lancer. Konon jika seorang wanita yang pertama kali hamil dan merupakan keturunan raja tidak melakukan ritual ini wanita hamil itu akan "dipingit", hal ini dilakukan agar bayi tidak lambat saat akan dilahirkan. Acara tujuh bulanan ini dilakukan dengan berbagai kegiatan, diantaranya acara pembalutan kelapa dengan kain kuning oleh tetua yang bertugas dan acara lainnya.

Dalam acara tujuh bulanan ini ibu hamil menggunakan pakaian terbalut dengan kain kuning sebatas dada, di bawah menyingkap daun daun tebu hitam yang berdiri tegak bagai tiang penyangga. Acara mandi-mandian ini dihiasi dengan benang-benang yang direntangkan dari tiang ke tiang, tiang yang digunakan biasanya tebu (manisan) serta tombak, sehingga kemudian membentuk ruang persegi empat pada benang-benang tersebut diberi mayangmayang pinang dan kelengkapan lainnya. Acara mandi-mandian ini dilakukan dengan beberapa rangkaian, yang pertama yaitu mandi baya, mandi bepapai dan babudus. Mandi baya yaitu mandi menggunakan banyu baya atau air yang disiapkan oleh bidan atau tetua khusus. Dinamakan bepapai pula karena memapai, yaitu mandi yang dilakukan dengan memercikkan air dengan berkas daun-daunan. Dilajutkan dengan mandi babudus.

"Oleh tetua dengan kebaya encim dan kakamban bermotif manggis, perempuan itu didudukkan pada kuali tanah terbalik yang telah dialasi anyaman bamban. Sebiji anak kelapa yang baru menuaskan beberapa helai daun ia pangku hingga menutupi perut yang telah sebesar kuantan-kuali tanah pula. Kelapa itu dibalut kain kuning, seluruh bagian pagar mayang ini juga dibalut warna serupa." (Miranda \& Avesina, 2018, hlm. 11)

Data tersebut menjelaskan tentang beberapa rangkaian acara dari kegiatan ritual tujuh bulanan. Kuali tanah yang diduduki melambangkan pecahnya ketuban, sebiji kelapa yang dipangku melambangkan bayi. Upacara ini bertujuan untuk menolak kejahatan dan mendapatkan keselamatan. menurut kepercayaan masyarakat Banjar, bahwa wanita yang sedang hamil mudah diganggu makhlik-makhluk halus yang jahat.

Rangkaian acara pada tian mandaring dilanjutkan dengan acara mandi-mandian yang selanjutnya yaitu babudus dalam bahasa Banjar, acara ini dilakukan dengan proses menyiramkan air kepada ibu hamil yang telah dicampur dengan bunga dan bahan-bahan lainnya, yang dilakukan oleh ibu mertua, ibu, dan para tetua secara bergantian.

"perlahan air diciduk dengan gayung tempurung dari tajau kuningan. Air itu diambil dari pusara sungai yang kemudian didoakan oleh bidan. Bunga mawar, melati, dan dua pasang hiasan daun nipah berbentuk lipan turut menambah kesakralan. Perempuan dengan rambut hitam panjang berhias bando melati dengan sepasang kembang nagasari itu memejamkan mata ketika air mulai jatuh dari kepala." (Miranda \& Avesina, 2018,, hlm. 11)

Data di atas menjelaskan tentang cara-cara yang dilakukan dalam acara mandi-mandian babudus. Mandi babudus 
dilakukan dengan menyiramkan beberapa air yaitu banyu sungai Kitanu, banyu baya, yang sebelumnya telah dicampur dengan air yang telah dibacakan do'a-do'a seperti do'a yasin dan do'a lainnya. Tujuan dari mandimandi ini agar ibu hamil dapat terbebas dari kejahatan roh halus yang hendak menjahatinya.

Kegiatan selanjutnya yaitu pemecahan selubung mayang yang kemudian dilanjutkan dengan keluarga mertua mengguncangkan sebiji kelapa gading tepat di atas kepala calon ibu muda. Parang di tangan kanan memecah kelapa menjadi dua, air merembas dari sela bulir mayang, dan perempuan yang mengandung diharapkan dapat meminum tetesan air kelapa.

"Lidah si calon ibu muda terulur ke depan, susah payah ia menadah air kelapa. Setelah beberapa kali akhirnya ada juga tetes air kelapa yang bisa ia teguk."

(Miranda \& Avesina, 2018, hlm. 13)

Rangkaian acara tujuh bulanan kemudian diakhiri dengan proses pelepasan bagian mayang dari selubung, kemudian mayang pinang yang masih berwarna putih kekuningan disatukan dengan mayang yang berwara hijau yang sebelumnya telah direndam dalam air semalaman. Selanjutnya dilanjutkan dengan mencipratkan air yang telah dicampur dengan berbagai macam bunga ke bagian perut, bahu dan kepala calon ibu muda menggunakan sepasang mayang. Selanjutnya perempuan berperut kuali dipapah masuk ke dalam rumah oleh suaminya sebelum adzan ashar berkumandang. Kegiatan ini bertujuan agar proses kelahiran bayi nantinya berjalan dengan lancer, dan juga selamat.

Ritual mandi-mandian yang terus dilakukan oleh masyarakat Banjar sampai saat ini. Hal menunjukkan bahwa kearifan lokal yang ada pada daerahnya sangat bermakna baik bagi kehidupan masyarakat Banjar sendiri ataupun untuk memperkenalkan identitas budaya yang dimiliki oleh masyarakat Banjar. Ritual bagi masyarakat Banjat menjadi acara yang sangat sakral dan penting, karena kepercayaan mereka yang masih mempercayai hal-hal yang berbau ghaib. Tidak hanya itu, ritual oleh masyarakat Banjar juga dijadikan sebagai warisan secara turun temurun.

\subsection{Kearifan Lokal Masyarakat Dayak}

Pada novel Jendela Seribu Sungai banyak sekali menjelaskan tentang pelaksanaan ritual yang ada pada masyarakat Dayak. Berikut akan kami jelaskan beberapa ritual yang masih ada pada masyarakat Dayak berdasarkan novel Jendela Seribu Sungai:

\subsubsection{Mandiwata Bapanaik dan Aruh Ganal}

Mandiwata Bapanaik adalah upacara yang dilakukan para balian (tabib tradisional Dayak) dengan tujuan menurunkan para dewa, yang dilaksanakan sebelum palas (penyucian). Ritual ini dilakukan dengan memanjatkan do'a-do'a yang dibacakan oleh balian dengan asap dupa dan balian menggunakan gelang di pergelangan kakinya yang kemudian menarikan tarian khas dari daerah Dayak yang diiringi dengan tabuhan gendang. Do'a yang dipanjatkan oleh balian dalam ritual ini sangat beragam diantaranya:

"Bubuhan ruh gaib, ruh jahat, ruh ijin, ruh setan tulakan alih sida jauhakan kaluar langit, kaluar gunung sebab sida anu jaya, anu sakti, anu kuwasa. Pati kami manusia mamasang sabuk dahupa, sabuk dumarin kakusnya jadi 
tumpakan, jadi titian, jadi jambatan nang bahandung ke balai langit, balai manang, ka balai ratu dewata. Di balai baludan waku gagaduhannya. Balian ranggan mula ada, balian mambur mula jadi. Balian bawalu badangsanak nang digaduhnya kitab balian, kitab bawandut, kitab basusun, kitab balapis. Titiannya di alam patilarahan, di alam patilarahan, di alam siwarak walu." (Miranda \& Avesina, 2018, hlm. 3)

Data di atas merupakan beberapa mantra yang dibaca saat upacara Mandiwata Bapanaik. Mantra ini dibacakan oleh para balian (tabib tradisional Dayak) yang sebelumnya telah terpilih dan dipercaya dapat membacakannya dengan baik. Ritual ini dilakukan sebelum dilaksanaknannya penyucian bagi wanita yang sedang hamil untuk pertama kalinya. Ritual ini sampai saat ini masih dilakukan oleh masyarakat Dayak, mereka percaya bahwa para dewa akan turun untuk turut mendoakan ibu yang sedang hamil beserta bayinya. Ketika proses pembacaan doa dengan asap dupa telah selesai dilanjutkan dengan prose bapalas atau penyucian.

"Darah ayam dipercikkan ke lantai, enam tiang utama balai, dan seluruh permukaan meja panggung lalaya tempat sasaji diletakkan. Lalu, perlahan darah ayam yang telah berpadu air ruas bambo menetes ke tanah dari celah lantai." (Miranda \& Avesina, 2018, hlm. 4)

Proses bapalas atau penyucian pertama kali dilakukan dengan proses penyembelihan darah ayam yang kemudian hanya diambil darahnya. Darah dari ayam yang telah disembelih kemudian dipercikkan pada enam tiang utama yang ada pada area upacara (biasanya dilakukan di balai). Pada meja diletakkan sesaji yang sebelumnya telah disiapkan, biasanya berupa sayur mayur, air, dan bahan lainnya. Sesaji ini disajikan dengan harapan para dewa yang turun untuk menyaksikan upacara. Setelah proses bapalas dilanjutkan dengan menggelar selembar tikar oleh lelaki yang menjadi penonton dalam ritual ini.

"Malam ini tikar itu akan menjadi tumpuan bakul beras dan para balian. Bakul-bakul rotan yang sengaja tak selesai dianyam pada bagian teratas disusun berjajar. Ada yang besar dan kecil dengan motif gigi ikan gabus, daun pakis, hiris gagatas, dan lain sebagainya. Setiap bakul mewakili jumlah panen kepala keluarga yang menyelenggarakan aruh malam ini. Lalu sebuah bakul paling besar dengan motif wayang yang menghimpun beras seluruh keluarga akan dinaikkan tepat ke puncak lalaya." (Miranda \& Avesina, 2018, hlm. 5)

Balian yang telah selesai menyiapkan bakul-bakul rotan pada tikar akan melanjutkan dengan mengambil minyak kelapa yang sebelumnya telah disiapkan. Selanjutnya balian meletakkan semenggar mayang pinang di tengah susunan bakul, yang kemudian pada bagian atas mayang yang masih kuncup berderet-deret dengan daun sirih dan juga kapur. Bakul-bakul tadi kemudian akan didoakan oleh para balian. Setelah selesai didoakan bakul-bakul akan disebar ke atap panggung lalaya yang dipersiapkan sebagai tempat persembahan. Tempat persembahan ini berbentuk payung yang berundak, dan sangkar yang serupa dengan rumah beratap. Pada proses persembahan ini gandang minjangan ditabuh oleh yang bertugas, dan para lelaki mulai mengitari areal upacara untuk menarikan tarian kanjar angin berputar. Setelah tarian kanjar angin berputar selesai ditarikan kemudian para balian duduk dengan beralas selembar tikar dan membacakan 
mantra pembuka yang dibaca dalam hatinya.

"U.... badiri balian jaya, balian sakti.

Balum ada bumi langit kau sudah badiri jadi balian, nang manggaduh di pucuk tihang langit, tihang aras, mualilulah. Nang manggaduh di burit tihang gumi, di bawah tujuh lapis alkiptulah." (Miranda \& Avesina, 2018, hlm. 6)

Data di atas merupakan do'a yang dipanjatkan para balian yang dilakukan dengan mata terpejam dan telunjuk mereka dicelupkan secara bergantian pada semangkuk minyak kelapa. Minyak yang menempel pada telunjuk mereka kemudian dipercikkan ke udara lalu dilanjutkan dengan membalurkan ke kepala. Proses ini bermakna untuk menyucikan pikiran mereka dari segala kesibukan atau urusan di dunia.

Ritual ini bagi masyarakat Dayak menjadi salah satu acara yang wajib untuk dilakukan dengan tujuan agar bayi dan calon ibu yang sedang hamil dapat dido'akan oleh para dewa dan juga terhindar dari kejahatan makhlukmakhluk halus. Sama halnya dengan masyarakat Banjarmasin, ritual oleh masyarakat Dayak juga menjadi salah satu kearifan lokal budaya yang diwariskan secara turun-temurun.

\subsubsection{Proses Tatamba}

Tatamba merupakan ritual pengobatan tradisional masyarakat Dayak menggunakan bahan-bahan tradisional yang biasanya didapatkan dari hutan. Proses tatamba dilakukan oleh balian (tabib tradisional) yang sudah berpengalaman. Proses tatamba ini juga diakukan dengan cara pembacaan mantra-mantra yang dipercaya dapat menghilangkan atau menyembuhkan penyakit. Mantra merupakan suatu bacaan atau doa-doa yang dipanjatkan oleh masyarakat dayak dalam berbagai peristiwa ataupun keadaan. Di suku Dayak mantra biasanya banyak dibacakan oleh balian. Jenis-jenis mantra pada masyarakat dayak sangat banyak sekali, diantaranya mantra pengobatan, mantra bercocok tanam, mantra pengembalian hasil alam, mantra perkawinan, mantra kelahiran, mantra sirap dan lain sebagainya.

"Buka lawang kulit, lawang darah, lawang daging. Kalu ada penyakit dalam darah, dalam daging, dalam kulit, dalam jantung, ambilkan ulih awak habis-habis, tundungakan, rajahakan." (Miranda \& Avesina, 2018, hlm. 155)

"Hancurkan penyakitnya dalam darah. Jadikan air, jadikan angin, titik air mula ada, mula jadi." (Miranda \& Avesina, 2018, hlm. 155)

Kata "lawang" pada doa yang dipanjatkan pada proses tatamba memiliki arti "pintu". Doa yang dipanjatkan balian pada data di atas memili arti yaitu "buka pintu kulit, pintu darah, pintu daging. Jika ada penyakit dalam darah, dalam daging, dalam kulit, dalam jantung, kamu bisa mengambilnya sampai habis". Pada doayang dipanjatkan itu balian meminta kepada Tuhan yang mereka percayai, kemudian pada doa yang kedua pula balian juga kembali meminta. Data di atas merupakan beberapa bacaan mantra yang dibacakan balian ketika mengobati orang-orang yang sakit. Pada proses tatamba balian tidak hanya dilakukan dengan membacakan mantra saja, akan tetapi juga menggunakan tanaman-tanaman yang mereka dapat dari hutan. Balian juga membacakan mantra pada segelas air lalu meniupnya dan air yang telah ditiup dengan pembacaan mantra tersebut 
diminum oleh orang yang sakit. Mereka percaya bahwa dengan membacakan mantra dan hanya menggunakan tanaman yang didapatnya dari hutan dapat menyembuhkan orang-orang yang sedang sakit dengan cepat. Kepercayaan ini mereka lakukan secara turun-temurn dan tetap dipertahankan sampai sekarang.

Proses tatamba oleh masyarakat Dayak selalu menjadi hal yang paling penting, karena masyarakat Dayak lebih percaya kepada pengobatan alami yang dilakukan oleh dukun atau balian dari pada pengobatan modern di rumah sakit yang dilakukan oleh dokter dan bidan. Masyarakat Dayak selalu mengajari anak muda pilihan yang dianggap mampu untuk melakukan kegiatan tatamba. Hal ini menunjukkan bahwa ritual yakni kegiatan tatamba menjadi hal yang wajib yang selalu diwariskan secara turuntemurun.

\subsubsection{Bagandang Nyiru/Upacara Wadian}

Bagandang Nyiru merupakan ritual untuk memanggil pulang anak yang diyakini disembunyikan hantu. Disembunyikan hantu di sini bukan berarti tubuh dari anak itu hilang, akan tetapi diartikan sebagai jiwa seseorang yang dikuasai oleh hantu atau yang biasa kita sebut dengan kerasupan roh halus atau dengan bahasa lainnya kesurupan. Proses ritual bagandang nyiru biasanya dilakukan oleh balian dengan menggunakan beberapa bahan-bahan dari tanaman-tanaman yang didapat dari hutan. Salah satu yang membuat ritual ini bisa dibilang unik, yaitu dalam proses pengobatan balian juga menggunakan kalung yang dibuat dari akar pohon jariangau, yang sebelumnya telah dibacakan doa atau mantra-mantra. Tumbuhan jariangau ini berbentuk seperti rumput tetapi tinggi, biasanya tumbuh pada tanah yang basah dengan daunnya yang rimpang dan baunya yang sangat kuat. Bagian yang biasanya digunakan sebagai bahan obat-obatan pada tumbuhan ini adalah rimpangnya (batangnya).

"Bayang-bayang kami tidak tegak lagi, Bunga tampak pulas di pangkuan $\mathrm{Bu}$ Sheilla. Pada lehernya terbelit akar jaringau yang dijalin serupa kalung oleh Damang Isman. Lalu pada telapak tangan, dahi, dan kaki, terdapat goresan kunyit bercampur kapur. Aku tidak tahu apa sakit kepala Bunga memang berkaitan dengan hal yang kasat atau memang ia kelelahan berjalan kaki? Hanya saja, peluh yang membanjiri wajah meski suhu tubuhnya dingin kini telah berhenti." (Miranda \& Avesina, 2018, hlm. 217)

Data di atas menjelaskan proses Bagandang Nyiru yang dilakukan oleh damang Isman terhadap Bunga yang pada saat itu dirasuki oleh makhluk halus ketika memasuki hutan. Proses bagandang nyiru dilakukan dengan membacakan mantra dan menggunakan dedaunan atau tumbuhan pilihan. Lalu pada telapak tangan, dahi, dan kaki pada pasien diolesi bahan-bahan yang digunakan dalam proses pengobatan.

Sama halnya dengan proses tatamba yang dilakukan untuk mengobati orang sakit, ritual bagandang nyiru ini juga dilakukan bagi orang yang sakit karena gangguan makhluk halus. Ritual bagandang nyiru ini juga menjadi salah satu ritual di Dayak yang selalu dijaga dan juga diwariskan secara turun-temurun.

\section{PENUTUP}

\section{Simpulan}

Berdasarkan pembahasan yang berkaitan dengan ritual pada masyarakat Banjar dan Dayak maka 
dapat disimpulkan bahwa pada masyarakat Banjar terdapat beberapa ritual yang masih ada dan tetap dipertahankan di era modern ini. Begitu juga pada masyarakat Dayak yang masih mempertahankan nilai-nilai ritual yang tetap terjaga dan diwariskan secara turun temurun. Mereka mengangggap bahwa ritual yang mereka dapatkan dari warisan turun temurun sebagai suatu kebanggaan dan perlu dipertahankan dan dijaga itu juga memiliki beberapa perbedaan dan persamaan.

Ritual yang ada pada masyarakat Banjar cenderung dilakukan sebagai rasa syukur terhadap nikmat yang diberikan Tuhan. Ritual juga dilakukan sebagai acara sacral yang wajib dilakukan bukan hanya mensyukuri nikmat dari Tuhan, akan tetapi sebagai hal yang dipercaya dapat mencegah segala kejahatan, terutama kejahatan dari makhluk ghaib. Ritual pada masyarakat Dayak juga dilakukan sebagai rasa syukur yang dilimpahkan Tuhan mereka pada masyarakat Dayak. Ritual oleh masyarakat Dayak dilakukan oleh orang-orang yang telah dipercaya dan sudah berpengalaman, yaitu seorang balian.

Ritual yang ada pada masyarakat Banjar dan Dayak memiliki persamaan yaitu sebagai suatu warisan yang diwariskan secara turun-temurun. Ritual dilakukan sebagai bentuk rasa syukur pada Tuhan yang mereka percayai, dan juga sebagai bentuk permohonan do'a agar dijauhkan dari segala bahaya serta gangguan dari makhluk ghaib. Perbedaan antara ritual masyarakat Banjar dan Dayak terletak pada proses yang dilakukan dalam kegiatan ritual itu, serta kepercayaan yang mereka percayai.

\section{DAFTAR PUSTAKA}

Amiruddin. (2017). Wujud Budaya Dalam Novel Teguh Anak Jadah Karya A.D. Donggo (Kajian Antropologi Sastra). Jurnal EDUKATA, 4(2), 159-168.

Astutik, ika dwi. (2012). budaya jawa dalam novel tirai menurun karya NH. Dini (Kajian Antropologi Sastra). 01, 1-11.

Indrawati. (2020). KARYA MIRANDA SEFTIANA DAN AVESINA SOEBLI KAJIAN ETNOLINGUISTIK ). 16(2), 215230.

https://doi.org/https://doi.org/1 0.26499/und.v16i2.2839

Miranda, S., \& Avesina, S. (2018). Jendela seribu sungai. PT. Grasindo.

Rafiq, A. (2013). RELASI DAYAKBANJAR DALAM TUTUR MASYARAKAT DAYAK MERATUS. 12(1), 117-146. https://doi.org/http://dx.doi.org /10.18592/al-banjari.v12i1.451

Ratna, N. K. (2011). Antropologi sastra: Peranan unsur-unsur kebudayaan dalam proses kreatif. Pustaka Pelajar.

Ratna, N. K. (2013). Teori, metode, dan teknik penelitian sastra. Pustaka Pelajar.

Sulastri, S. (2017). Unsur-Unsur Budaya Dayak Iban Dalam Novel Keling Kumang Karya Ray Masri Sareb Putra. Jurnal Pendidikan bahasa, 6(1), 37-50.

Wanti, K. (2014). Representasi Kebudayaan Masyarakat Suku Lio dalam Novel Ata Mai. $S M K$, PENGEMBANGAN BAHAN AJAR TEKS PROSEDUR KOMPLEKS DALAM PEMBELAJARAN BAHASA INDONESIA UNTUK KELAS X Artifa, 2(7), 700-709. 